\title{
Dilematis Antara Kesulitan Siswa Dengan Guru Dalam Pembelajaran Daring Pada Masa Pandemic Covid-19: Sebuah Upaya Aksidental MTs. Muhammadiyah Wuring
}

\author{
Mohammad Fitri ${ }^{1}$, Murniati ${ }^{2}$, Gis la Nuwa ${ }^{*}$ \\ ${ }^{1}$ Prodi Ekonomi IKIP Muhammadiyah Maumere, Jln. Jenderal Sudirman Waioti Maumere, NTT \\ ${ }^{2}$ Prodi Matematika IKIP Muhammadiyah Maumere, Jln. Jenderal Sudirman Waioti Maumere, NTT \\ ${ }^{3}$ Prodi PPKn IKIP Muhammadiyah Maumere, Jln. Jenderal Sudirman Waioti Maumere, NTT \\ Corresponding Email : gustavnuwa123@gmail.com
}

\begin{abstract}
The purpose of this study was to determine students' difficulties in online learning and to determine the efforts of teachers in overcoming student difficulties in online learning during the Covid-19 pandemic. The method used in this research is a descriptive qualitative approach by describing the teacher's efforts in overcoming student difficulties in online learning during the Covid-19 period at MTs. Muhammadiyah Wuring. This study uses data collection techniques, namely observation, interviews, and documentation. The results of this study can be seen from several student difficulties in online learning such as a) absence of $4 \mathrm{G}$ networks, b) reduced income c), assignment methods and d) absence of Android phones. The teacher's efforts in overcoming student difficulties in online learning such as a) assignment methods, b) providing motivation, c) providing advice, d) providing online explanations, e) installing Wifi. By knowing the various difficulties of students and the efforts of teachers in overcoming student difficulties in online learning, researchers hope that all of us, especially schools, teachers, parents, and the government to make input in the future.
\end{abstract}

Keywords:

Teacher Efforts, Student Difficulties, Online Learning, Covid-19 Pandemic

\begin{abstract}
Abstrak
Tujuan dari penelitian ini adalah untuk mengetahui kesulitan siswa dalam pembelajaran daring dan untuk mengetahui upaya guru dalam mengatasi kesulitan siswa dalam pembelajaran daring selama pandemic Covid-19. Metode yang digunakan dalam penelitian ini adalah pendektan kualitatif deskriptif yaitu dengan menggambarkan upaya guru dalam mengatasi kesulitan siswa dalam pembelajaran daring pada masa covid-19 di MTs. Muhammadiyah Wuring. Penelitian ini menggunakan teknik pengumpulan data yakni observasi, wawancara, dan dokumentasi. Hasil dari penelitian ini dapat diketahui dari beberapa kesulitan siswa dalam pembelajaran daring seperti: a)ketiadaan jaringan $4 \mathrm{G}$, b)pendapatan berkurang, c) metode penugasan, dan d)ketiadaan HP android. Adapun upaya guru dalam mengatasi kesulitan siswa dalam pembelajaran daring seperti: a)metode penugasan, b)memberikan motivasi, c)memberikan nasehat, d)memberikan penjelasan secara daring, dan e)pemasangan Wifi. Dengan mengetahui berbagai kesulitan siswa dan upaya guru dalam mengatasi kesulitan siswa dalam pembelajaran daring, peneliti berharap untuk kita semua terutama sekolah, guru, orang tua, dan pemerintah untuk menjadikan masukan kedepannya.
\end{abstract}

\section{Kata Kunci:}

Upaya Guru, Kesulitan Siswa, Pembelajaran Daring, Pandemic COVID-19

\section{A. PENDAHUlUAN}

Pada tahun 2020 ini, dunia diguncangkan oleh munculnya sebuah virus misterius yangdikenal dengan COVID-19 (Corona Virus Disease 2019). Awal munculnya virus ini pertama kali ditemukan di kota Wuhan, China pada akhir Desember 2019. Virus ini menular dengan sangat cepat dan telah menyebar ke hampir semua negara, termasuk Indonesia, hanya dalam waktu beberapa bulan.Seluruh segmen 
kehidupan manusia di bumi terganggu, tanpa kecuali dalam bidang pendidikan. Banyak negara memutuskan menutup sekolah, perguruan tinggi, maupun universitas, termasuk Indonesia. Krisis benar-benar datang tiba-tiba, pemerintah di belahan bumi manapun termasuk Indonesia harus mengambil keputusan untuk menutup sekolah dan mengurangi kontak secara langsung demi menyelamatkan hidup. Merebaknya kasus pademi Covid-19 sejak Desember 2019 sampai saat ini mengharuskan seluruh aktivitas belajar mengajar bagi peserta didik untuk sementara waktu dilakukan di rumah. Dalam rangka mencegah meluasnya penularan Covid19 pada warga sekolah khususnya Kementerian Pendidikan dan Kebudayaan mengeluarkan Surat Edaran Nomor 3 Tahun 2020 Tentang Pencegahan Corona Virus Disease (COVID-l9) Pada Satuan Pendidikan yang menyatakan bahwa meliburkan sekolah dan perguruan tinggi (Kemdikbud RI, 2020). Hal ini dilakukan untuk memutus mata rantai penyebaran Covid-19, sebagai gantinya kegiatan pembelajaran dilakukan di rumah untuk semua jenjang pendidikan, baik negeri maupun swasta guna melindungi warga sekolah dari paparan Covid-19. Penerapan pembelajaran daring sejalan dengan adanya Permendikbud Nomor 119 Tahun 2014 Tentang Penyelenggaraan Pendidikan Jarak Jauh (PJJ) Pada Jenjang Pendidikan Dasar dan Menengah.

Untuk mengisi aktivitas belajar mengajar, pemerintah mengambil kebijakan pembelajaran dilakukan melalui pembelajaran daring, baik menggunakan handpone, PC, atau laptop. Dalam hal ini tentunya teknologi memiliki peran yang sangat penting untuk memfasilitasi dalam interaksi, berkomunikasi serta penyajian agar proses pembelajaran berjalan dengan baik (Thoms \& Erylmaz, 2014).Menurut Isman (2016) pembelajaran daring merupakan pemanfaatan jaringan internet dalam proses pembelajaran. Dengan pembelajaran daring siswa memiliki keleluasan waktu belajar, dapat belajar kapanpun dan dimanapun. Sistem pembelajaran daring (dalam jaringan) merupakan sistem pebelajaran tanpa tatap muka secara langsung antara guru dan siswa tetapi dilakukan melalui online yang menggunakan jaringan internet. Hal ini sesuai dengan Kementerian Pendidikan dan Kebudayaan Republik Indonesia terkait Surat Edaran Nomor 4 Tahun 2020 tentang Pelaksanaan Kebijakan Pendidikan dalam Masa Darurat Penyebaran Corona Virus Disease (COVID-19), dalam surat edaran tersebut dijelaskan bahwa proses belajar dilaksanakan di rumah melalui pembelajaran daring dilaksanakan untuk memberikan pengalaman belajar yang bermakna bagi siswa. Pembelajaran daring bertujuan memberikan layanan pembelajaran bermutu dalam jaringan yang bersifat masif dan terbuka untuk menjangkau peminat yang lebih banyak dan lebih luas. Manfaat dari pembelajaran daring salah satunya untuk meningkatkan keterjangkauan pendidikan dan pelatihan yang bermutu melalui penyelenggaraan pembelajaran daring (dalam jaringan).

Pembelajaran daring dirasakan sangat efektif untuk mencegah penyebaran Covid-19 di lingkungan pendidikan. Menurut Hartanto(2016) mengungkapkan bahwa teknologi yang murah dan mudah akan menghilangkan batasan ruang dan 
waktu yang selama ini membatasi dunia pendidikan. Pembelajaran daring membuat para orang tua senang dan tenang, dikarenakan dapat selalu bersama anaknyanya, dengan maksud meminalisir penyebaran Covid-19. Pembelajaran daring merupakan salah satu alternatif yang diterpakan dalam pembelajaran di dunia pendidikan salah satunya tingkat SMP/MTs. Siswa dapat berinteraksi dengan guru menggunakan beberapa aplikasi. Aplikasi ini dilakukan seakan-akan terjadi dalam pembelajaran dalam kelas, penggunaan aplikasi yang mudah digunakan, namun sering belakangan ini terjadi pencurian data pada pengguna sehingga kurang aman untuk digunakan dan penggunaannya koneksi internet yang besar (Nuryana, 2020). Selain itu dalam pelaksanaan pembelajaran tersebut, memunculkan berbagai masalah dalam sisi positif maupun sisi negatif. Akan tetapi, dalam pembelajaran daring ini tidak terlepas dari permasalahan ataupun hambatan yang menjadi faktor masalah dalam pelaksanaannya. Disatu sisi proses pembelajaran harus berjalan lancar. Dan disisi lain berbagai permasalahan mengiringi proses pelaksanaannya. Song, dkk. (2004) menyatakan bahwa kesulitan-kesulitan (problems) yang muncul dalam pembelajaran daring adalah suatu tantangan (challenge).

Hal ini juga terjadi hampir seluruh wilayah propinsi Nusa Tenggara Timur mengalami problem yang sama yaitu proses pembelajaran tak terkendalikan dengan baik. Dinas terkait menjadi bingung entah apa yang akan dibuatnya. Dunia pendidikan dikacaukan dengan ketidaksiapan para pemangku kepentingan dengan para pelaku pelaksana pendidikan. Atmosfir pendidikan yang selama ini bertumpu pada kegiatan tatap muka langsung antara guru dan muridnya menjadi chaos dengan tidak ada inovasi pembelajaran alternatif. Pemerintah setempat bingung, masyarakat bingung, dan siswa juga pun turut ikut bingung. Pemerintah seketikan mengkerdilkan diri dengan miskinnya terobosan alternatif. Demikian juga lembaga pendidikan seketika kehilangan tajinya ketika berhadapan dengan pandemi Covid 19. Hasil akhirnya, antara pemangku kepentingan saling menyalahkan. Gubernur menyalahkan Bupatinya, Bupati menyalahkan Kadis PPO, dekian pula selanjutnya. Pemerintah daerah menunggu intruksi dari pusat, seolaholah masalah proses pembelajaran menjadi tanggung jawab pusat. Demikian juga lembaga pendidikan menunggu instruksi dari dinas terkait untuk melanjutkan proses pembelajaran yang ideal. Intinya, pemerintah, lembaga pendidikan, dan guru saling mengharapkan yang berakibat pada diterlantarkan ribuan siswa yang terdapat didaerahnya.

Kenyataan tersebut didasarkan pada hasil wawancara terhadap salah satu seorang guru dan siswa di MTs. Muhammadiyah Wuring mengenai kesulitan siswa dalam pembelajaran daring yakni berkaitan tugas terlalu banyak, pulsa kuota terbatas, jaringan internet bermasalah, dan ada sebagian peserta didik yang belum memiliki handpone/PC dan sejenisnya. Adapun faktor permasalahan yang mempengaruhi kesulitan peserta didik yakni faktor sarana dan prasarana dan kondisi ekonomi keluarga peserta didik. Sehingga tidak efektif dan efisien di dalam pelaksannnya maka guru harus mengambil upaya atau solusi yang pasti agar anak didiknya bisa belajar dengan baik dalam mengatasi kesulitan yang terjadi terhadap anak 
didiknya. Oleh karena itu, diperlukan berbagai upaya guru dalam mengatasi kesulitan siswa dalam pembelajaran daring pada masa Covid-19 di MTs. Muhammadiyah Wuring.Akibat terdapat kesulitan siswa dalam pembelajaran daring, maka penelitibermaksud melakukan penelitian mengenai upaya guru dalam mengatasi kesulitan siswa dalam pembelajran daring pada masa Covid-19 di MTs. Muhammadiyah Wuring. Sehingga diharapkan respon yang diperoleh dapat menggambarkan proses pelaksanaan pembelajaran daring di tengah pendemi Covid-19 saat ini dan dijadikan informasi dasar bagi pihak-pihak terkait dalam menentukan kebijakan pembelajaran daring guna mengatasi kesulitan siswa dalam pembelajaran daring pada masa pandemi covid-19 di MTs. Muhammadiyah Wuring.

Penelitian ini menggunakan pendekatan kualitatif dengan metode deskriptif. Pendekatan kualitatif menurut Lexy J. Moloeng (2012) adalah prosedur penelitian yang menghasilkan data deskriptif berupa kata-kata tertulis atau lisan dari orang-orang atau perilaku yang diamati yang diarahkan pada latar belakang dan individu tersebut secara holistik. Sedangkan menurut Arikunto (2010) penelitian deskriptif adalah penelitian yang dimaksud untuk mengumpulkan informasi atau gejala yang ada yaitu keadaan menurut apa adanya pada saat penelitian dilakukan. Sumber data dalam penelitian ini adalah data primer dan data sekunder. Data primer menurut Arikunto(2013) adalah data yang dikumpulkan melalui pihak pertama, biasanya dapat melalui wawancara, jejak pendapat dan lainlain. Yaitu data diperoleh secara langsung dari sumber aslinya yang berupa observasi dan wawancara terhadap guru dan siswa. Sedangkan data sekunder menurut Sugiyono (2012) adalah sumber data yang diperoleh dengan cara membaca, mempelajari dan memahami melalui media lain yang bersumber dari literatur, bukubuku, serta dokumen. Biasanya data diperoleh dari data yang sudah ada.Teknik pengumpulan data yaitu observasi, wawancara, dan dokumentasi. Adapun proses analisis data, peneliti menggunakan analisis data kualitatif dengan model Miles dan Humberman.Adapun langkah-langkah Teknik analisis data menurut Sugiyono (2013)yaitu: 1) Reduction(reduksi data), reduksi data dalam penelitian ini memfokuskan pada upaya guru dalam mengatasi kesulitan siswa dalam pembelajaran daring pada msa pandemi covid-19 di MTs Muhammadiyah wuring, peneliti berpedoman pada tujuan utama dalam penelitian yakni untuk mengetahui kesulitan siswa dalam pembelajaran daring dan untuk mengetahui upaya guru dalam mengatasi kesulitan siswa dalam pembelajaran daring pada masa pandemi covid-19 di MTs. Muhammadiyah Wuring. 2)Display (penyajian data) dapat dilakukan dalam bentuk uraian singkat, bagan, hubungan antar kategori, flowchart, dan sejenisnya. dalam penelitian ini penyajian data yang digunakan disajikan dalam bentuk naratif yakni upaya guru dalam mengatsi kesulitan siswa dalam pembelajaran daring. 3) Conclusion drawing atau verification (kesimpulan)dalam penelitian ini diambil dari hasil analisis data di lapangan, peneliti berusaha menggambarkan bagaiman upaya guru riil dalam mengatasi kesulian siswa dalam pembelajaran daring pada masa pandemi Covid-19 di MTs. 
Muhammadiyah Wuring. Peneliti merumuskan kesimpulan kemudian memverifikasi hasil data yang diperoleh dilapangan. Kesimpulan diambil setelah menyatukan dan merangkum semua data kemudian menyajikannya menjadi data yang mudah dipahami.

\section{B. HASIL DAN PEMBAHASAN}

Berdasarkan data yang diperoleh dari lokasi penelitian terdapat beberapa poin penting yang ditemukan oleh penelitian sebagai berikut:

\section{Kesulitan Siswa Dalam \\ Pembelajaran Daring Pada Masa Covid 19}

Kesulitan

siswa

dalam

pembelajaran daring pada masa

pandemi Covid-19 di MTs

Muhammadiyah Wuring akan diulas sedalam mungkin berikut ini:

\section{a. Ketiadaan Jaringan $4 \mathbf{G}$}

Ketiadaan jaringan $4 \mathrm{G}$ untuk wilayah Sikka merupakan masalah klasik yang dialami oleh masyarakat. Dikatakan demikian, hampir sebagian daerah-daerah yang terdapat di Kabupaten Sikka belum memiliki akses jaringan 4G. MTs Muhammadiyah merupakan lembaga pendidikan yang berada kurang lebih $15 \mathrm{KM}$ dari titik kota kabupaten Sikka (arah Utara). Hampir seluruh siswanya berasal dari pulau-pulau yang terpisah dengan daratan Flores. Akses jaringan di tempat mahasiswa tinggal hampir pasti tidak ada. Jika siswa yang bersangkutan ingin mengikuti proses pembelajara secara daring jalan satu-satunya yaitu mereka harus menggunakan perahu menuju daratan Flores atau ke sekolah.

Jaringan $4 \mathrm{G}$ adalah jaringan yang menghasilkan kecepatan dalam berkomunikasi lebih lancar dan tanpa batas. Dengan menggunakan jaringan ${ }_{4} \mathrm{G}$ LTE, maka pengalaman berinternet pun menjadi lebih cepat dibandingkan saat menggunakan jaringan $3 \mathrm{G}$ dan berpengaruh kepada penggunaan internet lainnya. Sehinggajaringan $4 G$ sangat berpengaruh terhadap pembelajaran daring. Persoalan yang dialami oleh siswa di MTs. Muhammadiyah Wuring adalah tidak semua siswanya tempat domisilinya memiliki akses jaringan 4G. Selama Covid 19 MTs Muhammadiyah Wuring menerapkan pembelajaran daring yang berujung pada ketidaksiapan siswa dan guru dalam penerapan pembelajaran daring itu sendiri. Pembelajaran daring digunakan oleh guru dan siswa di MTs Muhammadiyah Wuring untuk melakukan semua aktivitas pembelajaran dengan cara mengakses informasi melalui internet baik materi, penugasan, ulangan,ujian, dan lain-lain. Namun tidak semua peserta didik mengikuti pembelajaran daring secara rutin.Salah satu faktornya karena ada beberapa peserta didik yang tinggal di daerah atau lokasi yang belum ada jaringan $4 \mathrm{G}$ atau jauh dari jangkauan signal. Dampak terhadap peserta didik yaitu mereka susah atau lambat dalam mengakses internet terutama segala informasi tugas, informasi grup, dan pengumpulan tugas. Salah satu keuntungan jaringan $4 \mathrm{G}$ dalam pembelajaran daring yaitu kecepatan dalam mengakses internet tanpa batas dibandingkan jaringan lainnya.

Menurut Ali Sadikin (2020) memaparkan salah satu fenomena pembelajaran secara daring yang dialami peserta didik adalah lemahnya jaringan dan mahalnya kuota di beberapa daerah terpencil. Kondisi seperti ini memicu ketidakefektifan proses pembelajaran secara daring pada daerah-daerah terpencil. Hal ini juga dialami oleh siswa yang ada di MTs Muhammadiyah Wuring. 


\section{b. Pendapatan}

\section{(Ekonomi)}

Sejak munculnya pandemi Covid-19 berdampak pada perekonomian keluargadan berimbas terhadap berkurangnya pendapatan keluarga. Pendapatan keluarga adalah jumlah penghasilan riil dari seluruh anggota rumah tangga yang digunakan untuk memnuhi kebutuhan bersama maupun perseorangan dalam rumah tangga. Menurut Soeranto (1996) ukuran pendapatan yang digunakan untuk tingkat kesejahteraan keluarga adalah pendapatan rumah tangga yang diperoleh dari bekerja. Salah satu faktor dari Covid-19 segala aktivitas diberhentikan tanpa kecuali. Sehingga berpengaruh terhadap pemasukan keuangan dalam keluarga sangat berkurang. Salah satu dampaknya dalam dunia pendidikan berkaitan dengan pembelajaran daring, peserta didik yang memliki orang tua yang terdampak Covid-19 tidak dapat mengikuti kegiaatan pembelajaran daring dengan rutin. Sebab, kondisi keuangan keluarga yang tidak memadai. Sehingga berdampak pada peserta didik seperti: pembelian kuota yang mahal, dan pembelian teknologi komunikasi dalam jaringan(gawai). Siswa menghadpi kesulitan sebagai hasil dari kelas yang dirancang dalam buruk dalam situasi krisis, dan siswa tidak puas dengan ketidakadilan dalam pendidikan dan kesulitan dalam memperolehh sumber daya pendidikan. demikian, pendapatan keluarga sangat berpengaruh terhadap proses pembelajaran daring peserta didik.

Pernyataan di atas diulas secara lengkap oleh Rizqon Halal Syah Aji (2020) yang menyatakan, dampak covid 19 pada pendidikan di Indonesia salah satunya adalah sarana dan prasarana yang kurang memadai. Indikator yang diulas di dalamnya adalah soal kondisi ekonomi siswa yang jauh dari sejahtera. Penguasaan teknologi informasi yang masih sangat minim akibat dari pembangunan yang tidak merata. Demikian juga yang terjadi di MTs Muhammadiyah Wuring, kondisi ekonomi keluarga masih sangat minim dan bahkan pengetahuan orang tua tentang pembelajaran daring masih sangat berkurang. Maka pada tataran ini sekolah sangat mempengaruhi produktivitasnya pada pertumbuhan ekonomi masyarakatnya. Masyarakat yang mapan secara ekonomi akan membentuk jati diri peserta didik sesuai dengan kebutuhan zaman yang menyertainya.

\section{Metode Penugasan (Alternatif)}

Menurut Syaiful Bahri Djamarah dan Aswan Zain (2013) metode penugasan adalah metode penyajian bahan dimana guru memberikan tugas tertentu agar siswa melakukan kegiatan belajar. Pada masa covid 19 MTs Muhammadiyah Wuring proses pembelajaran yang diterapkan sangat bervariatif, mulai dari metode daring, class room sampai dengan metode penugasan. Metode penugasan salah satu pilihan yang paling dominan diterapi oleh para guru di MTs Muhammadiyah Wuring. Hal ini diakibatkan oleh kurangnya pemahaman guru dalam penggunaan teknologi pembelajaran berupa daring. Akibat dari pilihan ini menyebabkan tugas yang diberikan kepada siswa semakin banyak dan menumpuk. Beban tugas yang sangat banyak tentu membuat siswa merasa terbebani dan tertekan secara psikologis. Siswa kesulitan dalam mengalokasikan waktu setiap tugas yang diberikan oleh guru, mana kekurangan ekonomi yang menerpa keluarganya berjalan beriringan dengan pandemic Covid 19. 


\section{Ketiadaan HP Android}

Menurut Satyaputra\& Aritonang (2016), android adalah sebuah sistem operasi untuk smartphone dan tablet. dimana sistem operasinya dapat diilustrasikan sebagai perantara antara device dan penggunaannya, sehingga pengguna dapat berinteraksi dengan devicenya dan menjalankan aplikasi yang tersedia pada device. Dalam masa pandemi Covid-19 segala aktivitas dilakukan di dalam rumah khususnya dalam dunia pendidikan. Untuk mempelancar kegiatan pembelajaran pemerintah menetapkan kebijakan dengan pembelajaran daring. Dalam pembelajaran daring di tuntut menggunakan teknologi komunikasi yang ada. Teknologi yang digunakan oleh guru dan siswa dalam berinteraksi yaitu handphone. HP berperan dalam media pembelajarn daring dan digunakan untuk membantu proses pembelajaran. Dengan dimaanfaatkan HP sebagai media pembelajaran, siswa dapat mengaakses semua materi atau informasi-informasi mengenai pendidikan yang diberikan oleh guru.

Kenyataannya tidak semua pesrta didik memliki HP anroid. Jangankan memiliki HP android, memegangnya saja belum pernah yang berujung pada ketidakpahaman siswa dalam mengoprasikannya. Salah satu faktornya adalah karena ada beberapa peserta didik yang memiliki orang tua yang belum mampu untuk membeli HP anroid. Akibatnya peserta didik tidak dapat mengikuti pembelajaran daring dengan lancar. Ada sebagian peserta didik mengikuti karena ada teman/tetangga yang memijamkan HP dan ada peserta didik tidak mengikuti sama sekali proses pembelajaran daring. Akibat lanjut dari kondisi seperti ini, peserta didik mengalami kesulitan dalam mengakses informasi dari guru ataupun teman lainnya mengenai tugas, ulangan, dan segala aktivitas pembelajaran daring. Demikian, ketiadaan hp anroid berpengaruh terhapadap proses pembelajaran daring.

4. Upaya Guru Dalam Mengatasi Kesulitan Siswa Dalam Pembelajaran Daring

\section{a. Metode Penugasan}

Guru tetap memberikan materi atau penugasan terhadap peserta didik dengan mengintegrasikan dua mata pelajaran atau lebih dalam satu tugas. Menurut Ade Nasihudin Al Ansori(2020) anak-anak yang mengikuti survei dari 29 propinsi berharap agar sekolah agar terlalu banyak memberikan tugas dan komunikasi dua arah antara guru dan murid dirasa lebih efektif. Selain itu sebelum memberikan tugas, guru harus merencanakan pemberian tugas secara matang, didasarkan pada minat dan kemampuan peserta didik, kesesuaian materi, guru dapat membantu menyediakan alat sarana yang diperlukan dalam pemberian tugas, dapat merangsang perhatian peserta didik dan realistis dan mengurangi tugas. Hal ini akan mengurangi beban siswa dalam melaksanakan pembelajaran di rumah pada masa Covid-19.

Penugasan merupakan alat atau prosedur yang digunakan untuk mengetahui atau mengukur sesuatu dalam suasana, dengan cara aturanaturan yang ditentukan (Arikunto, 2016). Sedangkan Sudjono berpendapat bahwa tes merupakan suatu cara atau prosedur yang perlu ditempuh dalam rangka pengukuran dan penilaian dibidang pendidikan (Sudjono, 2011). Tes untuk mengetahui hasil belajar dapat berbentuk pemberian tugas atau 
serangkaian pertanyaan-pertanyaan yang harus dikerjakan oleh peserta didik. Nilai yang diperoleh dapat melambangkan tingkah laku atau prestasi dari hasil belajar peserta didik (Rahmini dkk, 2018).

\section{b. Memberikan Motivasi}

Motivasi adalah hasrat, dorongan, dan kebutuhan seseorang untuk dapat melakukan aktivitas tertentu. selain itu motivasi belajar adalah sebuah penggerak atau pendorong yang membuat seseorang akan tertarik kepada belajar sehingga akan belajar secara terus memerus (Novianti, 2011). Motivasi belajar berperan untuk menumbuhkan rasa senang, gairah, dan semangat untuk belajar. motivasi yang tinggi dalam pembelajaran daring dapat menyebabkan keberhasilan dalam belajar peserta didik dalam pembelajaran daring sehingga akan meningkatkan semangat dan prestasi belajar siswa ditengah maraknya Covid-19. Oleh karena itu, diperlukan pendorong untuk menggerakkan siswa agar semangat belajar sehingga dapat memiliki prestasi belajar (Rimbarizki, 2017).

\section{c. Memberikan Nasehat}

Menurut Sukmawati (2016) strategi arahan dalam sebuah proses pendidikan meningkatkan daya perubahan yang signifikan bagi seorang siswa yang sebelumnya bersikap acuh tak acuh menjadi pribadi yang mencintai akan proses pembelajaran itu. Pendekatan seorang guru dalam situasi yang tak menentu seorang siswa dapat merubah suasana hati peserta didik. Peserta didik merasa diperhatikan dan bahkan merasa dirinya adalah bagian dari proses situ sendiri. Selain berperan memberikan motivasi, guru juga adalah penasehat bagi peserta didik juga bagi orang tua, meskipun mereka tidak memiliki latihan khusus penasehat. Guru juga harus memberikan nasehat atau halhal yang bersifat positif agar peserta didik tidak terlalu khawatir akan pandemi Covid-19.

\section{d. Pertimbangan Psikologis \\ Anak}

Disisi lain, guru juga harus memperhatikan mood belajar peserta didik agar tidak terlalu stres akibat tugas.Pertimbangan psikologis anak didik selama pandemic Covid 19 merupakan unsure yang paling utama diperhatikan oleh seorang guru. Dalam kondisi seperti ini peserta belajar mengalami depresi yang diakibatkan oleh berbagai faktor yang menimpa diri dan keluarganya. Kondisi proses pembelajaran yang tidak optimal dan konsisi jaringan yang tidak memadai menyebabkan seoarang anak bingung dan cemas. Perkembangan pengetahuannya tergantung pada kekuatan jaringan dan HP android. Belum lagi jika seorang siswa tidak memiliki HP android dan pulsa data, maka seketika mimpi seorang anak akan sirnah bersama ketidakjelasan proses pembelajaran itu. Menurut Didin Jamaludin, (2020) dalam penelitiannya mengungkapkan bahwa kondisi psikologi peserta didik selama pembelajaran online sangat mempengaruhi keberhasilan sebuah proses pembelajaran. Hal ini diungkapkannya hampir $>90 \%$ kondisi psikologis anak sangat terganggu.

Melihat kondisi seperti ini, guru di MTs Muhammadiyah Wuring mencoba memberikan pendekatan secara psikologis anak dengan cara 
mengidentifikasi seluruh persoalan siswa/siswi. Setelah itu melakukan kunjungan rumah bagi siswa yang kehilangan informasi selama proses pembelajaran daring. Dengan melakukan kunjungan rumah seorang siswa akan merasa nyaman dan diperhatikan dan pada akhirnya siswa yang bersangkutan termotivasi untuk kembali mengikuti proses pembelajaran.

\section{e. Memberikan Penjelasan Secara Daring}

Guru hendaknya mengajar daring dengan tetap memberikan penjelasan pada peserta didik , semata-mata tidak hanya dengan memberika tugas secara terus menerus sebab peserta didik juga butuh penjelasan untuk memahami materi yang dibahas.Guru dapat memanfaatkan penggunaan metode pembelajaran yang menarik, mudah dimengerti sehingga membuat siswa tertarik pada pembelajaran daring. Pembelajaran yang berkualitas akan menghasilkan hasil yang baik juga, sehingga akan tercipta suasana belajar yang menyenangkan. Di MTs Muhammadiyah Wuring, salah satu strategi yang digunakan oleh guru adalah menggunakan google classroom. Metode ini sampai dengan saat ini tetap digunakan dan bahkan sangat efektif sebagian siswa dan gurunya. Menurut Ericha Windhiyana Pratiwi (2020) dalam tulisannya berjudul "Dampak Covid 19 Terhadap Kegiatan Pembelajaran Online Di Sebuah Perguruan Tinggi Kristen Di Indonesia"menjelaskan bahwa, metode yang paling tepat digunakan oleh perguruan tinggi dalam proses perkuliahan adalah edmodo, Zoom meeting, dan google classroom. Ketiga metode ini sangat membantu para mahasiswa dan dosen dalam proses perkuliahan secara daring.

\section{f. Pemasangan Wifi}

Dalam proses pembelajaran pemanfaatan fasilitas belajar juga menentukan motivasi belajar siswa dan guru dalam pembelajaran daring. Pembelajaran daring memerlukan fasilitas yang menunjang pembelajaran seperti salah satunya wifi. Wifi merupakan sebuah teknologi yang memanfaatkan peralatan elektronik untuk bertukar data secara nirkabel melalui sebuah jaringan komputer, termasuk koneksi internet berkecepatan tinggi dan memiliki jangauan yang luas. Wifi sangat bermanfaat dalam pembelajaran daring bagi peserta didik yang mengalami kesulitan pulsa kuota. Dengan pemasangan wifi peserta didik akan merasa terbantu dalam pembelian kuota dan akan melaksanakan proses pembelajaran dengan rutin. Hal ini tentunya teknologi memiliki peran yang sangat penting untuk memfasilitasi dalam interaksi, berkomunikasi serta penyajian agar proses pembelajaran berjalan dengan baik (Thoms \& Erylmaz, 2014). Di MTs Muhammadiyah Wuring, selama masa Pandemi Covid 19 sekolah menambah pengadaan jaringan wifi demi memperlanjar aktivitas pembelajaran secara daring baik bagi guru dan siswa yang tidak memiliki pulsa data. Meskipun demikian, pengawasan dari pihak sekolah terhadap siswa yang menggunaka wifi tetap menekankan protokol kesehatan.

\section{SIMPULAN}

Berdasarkanhasil penelitian maka peneliti dapat menyimpulkan bahwa 
terdapat beberapa kesulitan siswa dalam pembelajaran daring pada masa pandemi Covid-19 yakni ketiadaan jaringan 4G, pendapatan berkurang (ekonomi), metode penugasan(alternatif), dan ketiadaan hp anroid. Adapun upaya guru dalam mengatasi kesulitan siswa dalam pembelajaran daring yakni metode penugasan, memberikan motivasi, memberikan nasehat, pertimbangan psikologis anak, memberikan penjelasan secara daring, dan pemasangan wifi. Dari hasil penelitian menunjukkan bahwa pelaksanaan pembelajaran daring belum efektif dalam proses pembelajaran sebab masih terdapat kesulitan yag di hadapi oleh peserta didik di MTS Muhammadiyah Wuring pada umumnyayakni sarana dan prasarana dan kondisi keuangan dalam melaksanakan pembelajaran daring belum memadai. peneliti berharap berbagai upaya di atas selayaknya bisa dijadikan masukan berharga untuk kita semua terutama sekolah, guru, orang tua, dan pemerintah. Terutama tugas guru untuk mencerdaskan siswa-siswi tetap ditunaikan meski tidak dapat bertatap muka secara langsung apalagi dimasa pandemi Covid-19 ini. Dengan demikian, siswa di MTs. Muhammadiyah Wuring tetap memperoleh haknya untuk belajar, berpikir, bertutur, dan bertindak ditengah adanya pandemi Covid-19.

\section{DAFTAR PUSTAKA}

Arikunto,S.2013.Prosedur Penelitian Suatu Pendekatan Praktik.Edisi

Revisi.Jakarta:PT.Rineka Cipta

Arikunto, 2016. Dasar-Dasar Evaluasi

Pendidikan. Jakarta: Bumi Aksara

Ali Sadikin, 2020. Pembelajaran Daring

Di Tengah Wabah Covid 19. Jurnal

Biodik, Vol. 6, No. 2. Hal. 1-7.
Baharin R. Halal,R, dll, 2020, Impact of Human Resource Investmen on Labor Productivity in ndonesia,Iranian Journal of Management Studies, 13 (1), Hal. 139-164.

httpps://doi.org/10.22059/ijms.201 9.280284 .673616

Didin Jamaludin, 2020. Pembelajaran Daring Masa Pandemi Covid-19 Pada Calon Guru: Hambatan, Solusi Dan Proyeksi. Digital Library UIN Gunung Djati

Djamarah, Syaiful Bahri dan Aswan Zain.2013. Strategi Belajar Mengajar. Jakarta : Rineka Cipta.

Ericha Windhiyana Pratiwi (2020), Dampak Covid 19 Terhadap Kegiatan Pembelajaran Online Di Sebuah Perguruan Tinggi Kristen Di Indonesia, Jurnal Perspektif Ilmu Pendidikan, Vol.34, No.1, hal. 1-8.

Hartanto, W. (2016). Penggunaan ELearning sebagai Media Pembelajaran. Jurnal Pendidikan Ekonomi, 10(1), 1-18.

Isman, (2016). Pembelajaran Moda Dalam Jaringan (MODA DARING).ISBN:978-602-361-045-7

Lexy J. Moloeng. Metodologi Penelitian Kualitatif,Edisi Revisi (Bandung : PT Remaja Rosdakary, 2012), hal. 4

MENDIKBUD RI, (2014). Peraturan Menteri Pendidikan Dan Kebudayaan Republik Indonesia Nomor 119 Tahun 2014 Tentang Penyelenggaraan Pendidikan Jarak Jauh Jenjang Pendidikan Dasar Dan Menengah. Jakarta: MENKUMHAM RI.

Menteri Pendidikan.(2020). Surat Edaran Nomor 3 Tahun 2020 Tentang Pelaksanaan Penndidikan Dalam Masa Darurat CoronaVirus (COVID-19). 
Novianti, N.R (2011). Kotrabusi Pengelolaan Laboraturium Dan Motivasi Belajar Siswa Terhadap Efektivitas Proses Pembelajaran. Jurnal Pendidikan Mipa. Edisi Khusus,1,158-166

Nuryana, Z. (2020). PANDUAN PENGGUNAAN ZOOM. US UNTUK PEMBELAJARAN ONLINE

Rahmaini dkk, 2018, Analisis Butir Soal Pendidikan Agama Islam Di SMKN 1 Sedayu Tahun ajaran 2017/2018. Jurnal Mudarrisuna, 8 (1) hal. 1-24.

Rimbarizki,R. 2017.Penerapan

Pembelajaran Daring Kombinasi Dalam Meningkatkan Motivasi Belajar Peserta Didik Paket C Vokasi Di Pusat Kegiatan Belajar Masyarakat (PKBM) Pioneer Karanganyar. J+Plus Unesa, 6(2), 1-2

Rizqon Halal Syah Aji, 2020. Dampak Covid 19 pada Pendidikan Di Indonesia: Sekolah, Keterampilan, dan Proses Pembelajaran. Jurnal: Sosial dan Budaya Syar-i. Vol. 7, No. 5, Hal 3950-402.

Satyaputra, Alfa \& Maulina Eva Aritonang (2016) Let's Build Your Android Apps With Android Studio. Jakarta : PT Elex Media Komputindo.

Sudjono, Anas, 2011, Pengantar Evaluasi Pendidikan. Jakarta: Raja Grafindo Persada.

Sugiyono. 2012. Memahami Penelitian Kualitatif. Bandung : ALFABETA .2013.Metode

Penelitian

Pendidikan Pendekatan

Kuntitatif,Kualitatif,Dan $R$ $\mathcal{E} D$. Bandung Alfabeta.

Sukmawati, 2016, Strategi Guru Menghadapi Siswa yang Malas Mengikuti Pelajaran Matematika Di SMAN 1 Lamasi. Jurnal
Pedagogy, Vol.1, No.1 Tahun 2017, Hal. 114-146.

Thoms, B., \& Eryilmaz, E. (2014). How media choice affects learner interactions in distance learning classes. Computers \& Education, 75, $112-126$.

\section{Internet}

Ade Nasihudin Al Ansori.(2020). Belajar di Rumah Akibat Corona COVID19, Ini pendapat dan harapan anak indonesia.https://m.liputan6.com/ health/read/42249699/belajar-dirumah-akibat-corona-covid-19-inipendapat-dan-harapan-anakindonesia diakses pada tanggal 12 April Tahun 2020 